\title{
THE DYNAMICS OF SURAKARTA BATIK: The Development of Batik Through Conservation by Revitalization and Reinterpretation in the Development Dynamics of Surakarta Batik
}

\author{
Dharsono $^{1}$ \\ ${ }^{1}$ Departement of Fine Art, Faculty of Fine Art and Design, Indonesian Institute of the Arts Surakarta, \\ Indonesia
}

\begin{abstract}
The study of "classic batik dynamics is focused on the dynamics of batik development. While the consumers have turned their attention to the motive of batik textile, the bourgeoisie of Indonesia has worn fine batik cloth or batik tulis (hand drawn batik) for formal occasion or party. The dynamics has ushered batik tulis (hand-drawn by canting, a copper vessel with spouted nib) to its exclusive throne. Classical batik thus became source of veneration, where subsequent batik production took its philosophy and inspiration. The objective of this study is to obtain the picture of Surakarta classical batik dynamics: (1) Classical view of Surakarta batik dynamics and (2) conservational view of Surakarta batik dynamics. Such an objective requires research measures or research method on batik dynamics, particularly in Surakarta region. This research is a qualitative research using cultural approach and refers to Javanese cultural teachings in line with cultural philosophy; it thus emphasizes data interpretation of specific cases. Analytical description of this study, therefore, emphasizes more on interactive model of qualitative data analysis using Javanese cultural approach. The result of interactive analysis is then examined with hermeneutical interpretive analysis, which is directed to interpret meaningful expression that people deliberately offered (interpretation on interpretation). This study has revealed (1) classical view of Javanese people when they see and understand things and behave accordingly with constant reference to the cultural source. "Javanese cultural process conforms to social dynamics, which refers to supreme cultural concept "sangkanparaningdumadi" (the origin and destination of mankind). The concept is also known, in Javanese culture, with the phrases nunggak semi(sprouting stump) or mutrani(to make offspring). (2) The conservational view has inspired subsequent batik production to refer to preservation model, i.e. conservation. The conservational development of batik in the form of revitalization and reinterpretation has resulted in the dynamics of Surakarta batik development.
\end{abstract}

Keywords: classic batik, the conservational development of batik, mutrani (to make offspring)

DOI: $10.7176 / \mathrm{ADS} / 74-04$

Publication date:July $31^{\text {st }} 2019$

\section{Introduction}

Batik is a panting or drawing on cloth using a toll called canting (a copper vessel with a spouted nib). The process of painting or drawing or writing on a cloth by a canting is thus called doing batik work. Doing batik work produces batik or batik work with various motifs and special features of respective batiks. The emergence of printing batik, although it is not as fine as hand-drawn batik, has contributed to the preservation of values that traditional hand-drawn batik has been retaining. Batik further development did not accelerate the waxing process, instead it has accelerated motif-drawing and coloring that produced batik motif cloth that virtually identical with batik. Such a batik cloth is called "batik printing". The dynamics of batik development has directed batik consumers' attention, the society has concerned with batik motif textile, while the Indonesian bourgeoisie has worn fine batik cloth (hand-drawn batik) for formal occasions or parties. The dynamics has ushered hand-drawn batik (batik canting) to its exclusive throne. Batik thus became source of veneration, where subsequent batik production and development took their philosophy and inspiration. Batik is a beauty (aesthetic), in Javanese culture point of view, which represents teachings it bears in its painted classical motif/pattern. Therefore batik is seen as a great Indonesian heritage that the world has recognized as both tangible and intangible cultural heritage.

\section{Objective}

The objective of the research is to obtain a picture of the dynamics of Surakarta classical batik: (1) Classical 
view on the dynamics of Surakarta Batik, and (2) Modern view on the dynamics of Surakarta batik.

\section{Research Method}

The research will examine problems by questioning classical view on the dynamics of Surakarta batik and how the modern society perceives batik dynamics, particularly in Surakarta region. The research, therefore, is a qualitative one using cultural approach that refers to Javanese cultural teachings along with Javanese cultural philosophy. The adopted approach emphasizes data interpretation of specific cases (Denzin, 1980: 100). Data collection is mainly conducted by in-depth interview that is adopted for its flexibility and openness. In addition, in-depth interview has no rigid and formal structure and can be conducted repeatedly with the same informants. The questions can be asked in more focused ways so that the collected information can be more detail and deep. The structure is employed to achieve significant depth of the collected information. The flexible technics will be able to obtain true information from the informants, especially regarding their feeling, attitude, and views on the existence of classical art artifacts. The interview technics will be employed for all informants selectively (sampling) based on adopted theoretical concepts. The interview technique is purposive in nature, thus the informant selection is a criterion basedselection where the selected informants are regarded as reliable data sources. However, other informants who likely have more accurate information and more knowledge on the subject will also be selected so that the informants selection might grows according to the necessity and robustness of data collection.

The analytical description of the present study will emphasize more on interactive model of qualitative data analysis, using Javanese cultural approach. The interactive analysis is employed to analyze qualitative data obtained from empirical data collection in order to obtain accurate results of classification and identification process. The model is adopted because it offers more characterizations to cover inputs and descriptions in a summary of data reduction and its conclusion. The qualitative data analysis model is employed along with the implementation of cycle system where the researcher always moves to explore the subject during the process (Rohidi 1992: 19-20).

The result of interactive analysis is then examined by hermeneutical interpretive analysis that refers to the interpretation of meaningful and deliberate human expression. This is an interpretation of interpretation of individual or group of individuals over their own situation. Any event or work has its own interpretation from its actor or maker. A work that is the result of interpretation is then exposed to readers or observers and is also perceived by interpretation. In hermeneutical analysis the researcher generates interpretation of a work as if it was recreated as a new meaning in accordance with the adopted cultural theory (Sutopo 1996: 29). Hermeneutics deals with how the problem arrives to the condition as it is expressed. Hermeneutics, therefore, is formulated as theory of impression operations with regard to cultural interpretations - as texts. Interpretation is affirmed as distinction of hidden meaning beneath a surface meaning. The task of hermeneutics is to reveal the understanding of text or world of text or reality conveyed by the text instead of creator's spirit (Poespoprodjo 1991: 117-118).

\section{Literature Review}

EdhiWuryantoro (1986: 1-15) said that the dynamics of Javanese classical batik is initially closely related to copy right of palace (keraton) status symbol in Java. The inscription in a rock from IX and X inform us about complicated inventories of proper textile motifs and types for the king or higher, middle, and lower palace officials.

Rajiman (1986: 96), in "Sejarah Surakarta" (History of Surakarta), described the story of Ny. Reksowicitro, a batik maker from Soniten, Surakarta, who was raised from her status as kawulo (ruled person) into an abdi dalem (royal servant) in keraton as an "Abdi Dalem Kriya" with the rank of "Hamong Kriya" for her skill. KRT Yosodipuro, in an interview, said that in the palace of Surakarta doing batik work skillfully was an honorable job and enables to put the children of the palace into higher position. Vertical mobility of Abdi Dalem Kriya that they desired had positive impact on their families' prosperity. It was true because they acquired significant economics facilities and their status was raised from lower noble rank. Palace batik maker as a noble rank is exclusively reserved for female batik artisan that was positioned as servant for keputrian (womanhood) palace. The title of Hamong Kriya she had acquired posed a responsibility for her to lead batik work in the palace. The phenomenon has influenced the existence of people batik that grows outside the palace and eventually went into the palace. 
Later batik has acquired legitimation as the King declared the now so-called classical batik as Palace batik.

Clifford Geertz (1981) said that after people batik craft went to the palace in Java Island, aristocrat label was attached to Javanese classical batik. Despite no change in original motif (particularly in ornamental symbol), as a form of ornamental design the soft touch of the court aristocratshas successfully identified the work as the product of palace. The so-called "Aristocrat Batik" is in fact a fine art work of batik tulis (hand-drawn by canting) that reflects the culture of Javanese high-class (nobility). Geertz called it as refinement culture. The statement is a note for legitimation process of folk batik (through the family company of Wicitran) raised its level as a batik company of the palace circle and labeled as aristocrat batik (hand-drawn batik dyed with soga by the palace). Popularity of the batik has won society's trust for hand-drawn batik produced by Wicitran's company. Handdrawn batik produced by the palace appeared so prominent and became characteristic of high-class. The finedyed batik has encouraged batik artisans (outside the palace) to bring their batik to be finely dyed in the palace and properly called as classical batik.

Sudarmono (1990), said that around 1769 the Susuhunan (title for ruling monarch) of Surakarta Hadiningrat issued a pranatan (decree) that "Jilamprang" motif was prohibited to wear by anyone except the Susuhunan and his descendants. In 1785 the Sultan of Yogyakarta initiated parangrusak (broken knife) pattern for his own interest. Then in 1792 and 1798 the pengageng (palace officials) issued further rules to restrict patterns to wear for certain occasions in the keraton such as sawatlar, parangrusak, cumengkirang and udanliris (1990:2).

Batik art as a cultural mode for the people to glorify their Creator was subtly animated as palace cultural production through the concept of Dewaraja culture. Classical batik then was labeled as aristocrat and its function shifted from the people's interest into that of the king to strengthen the position of the king. Such a significant value shift for the advantage of ruler's political interest has confirmed the existence of palaceproduced motifs. For example, in the composition of Surakarta style sidomukti batik the picture symbols were increasingly dominated by palace symbol that was placed over a pair of garuda birds and tree of life, temple (building), and throne. The geometrically arranged frames that underlined every basic ornamental unit also showed the increasingly dominance of palace cultural-ethic element. The predominant symbolic pictures did not abandon their original elements such as "semen" motif, but "sidomukti" motif has really reflected aristocratic label by its main symbols display. Various efforts have been exerted to legitimize batik as a cultural art creation of the palace. One effort was exerted by positive law through the promulgation of pranatan (rules) and prohibitions regarding dress code within the palace. However, it was just no more than normative law implementation. In XVII century batik was labeled as palace's cultural product, and consequently its function as people's consumer goods decreased. Batik served as social status symbol for its owner and moved farther from people hands (1990:7).

Sewan Susanto (1980) said that motif and patters of classical batik are composed base on repetition of "batik pattern". Batik pattern consists of combined motifs that are arranged according to the types of batik in conformity with standardized rules (pakem in Javanese). The arrangement of batik is a combined patterns that comprises main motif, filler (alternation) motif, and filled pattern. Classical batik coloring generally shows that the color of dark blue (wulung), dark brown (dragemsogan), and white are preferable as batik's ornamental background. In many respects those colors are easy to find in various plants that grow naturally. For example, kelengan (black-white) batik is made with basic color wulungwedelan or with black color that abundantly available. While dark blue color is extracted from plants of indigo family and black color form ketepeng leaves.

Kartosoeyono (1950) said that ornament and decorative pattern has also significance in visualization of symbols containing religio-magical values. Semen motif, for example, is illustrated with meru(mountain) symbol or tree as symbol of earth, bird as symbol of wind; serpent as symbol of water; fire as symbol of the sun that are supplemented with alternation of plants, animals and isen-isen in the form of lined dots (cecek in Javanese). Semen batik, its main motifs and its complements, will only get its meaning after those pictures are placed in one complete ornamental unit. For example, meru picture represents life elements thanks to the power given by fire, wind, and water that are illustrated, respectively, as flame or fire tongue, bird and serpent (sisik-sisik), which each obtained life from Nurcahyo. It seems that Javanese cosmogony teaches that the four natural elements of life basically exist within the self of every human being. Those illustrated symbols, therefore, will only significant if people able to examine and control his or her self against attitudes and characters represented by those symbols. Self-control attitude in Javanese religion is called Nur-rasa, a will basic (Nur) that animates good taste (will of the soul) and the will to create (culture).

With regard to color symbolism of classical traditional batik coloring it can be said that the adoption of batik 
coloring like yellow, white, red, blue, and black has become Javanese character that presumably the glorification of the First Cause. The meanings of those colors arebased on wind directions that have symbolical color values, namely east-white, south-red, west-yellow, north-black. While other colors,as combinations of the afore mentioned, stay in the middle as the fifth part. In Javanese mysticism the saying sederak sekawang angsal pancer (literally four brother and fifth the center of all) represents earth with black color that characterizes lawamah (vicious passion), fire with red color that characterize amarah (anger), wind with yellow color that characterize supiyah (good behavior), water with white color that characterize (honest), the center of earth with green that characterize kama or good behavior. It seems that those colors have significantly influenced the standard placement of colors in classical batik. The motifs of classical batik contain certain meanings and are considered significant by the Javanese. Moreover, the ornament of classical batik is expected to bring about the beauty, a beauty that produces harmonious combination between coloring and form composition of the ornament and its content. Batik art is expected to bring about the beauty of soul, composition, and coloring as symbolized in the ornament and its content in order to convey a complete picture in accordance with Javanese view of life, to convey symbolical meaning of Javanese cosmology of underworld and upper world.

Rahmad Subagyo (1981) said that Javanese people often combine upper world and underworld and middle world that is called two-in-one dualism (see Primadi 1995:16) or monistic dualism. Such a combination of two beliefs into one among Javanese society was known as syncretism ${ }^{1}$.

\section{DISCUSSION}

\section{Classical Batik}

Y. E. Jasper and Mas Pirngadi (1916:113-120), in their description, did not mention when exactly batik began to spread its cultural influence in Java (Indonesia). However, a report by G. P. Rouffaer in Jasper's book offered a complete account on the origin of Javanese batik, which was said brought by Indian merchants of Coromandel Coast until the end of Hindu's influence in Indonesia. Rouffaer's account emphasized technical aspects of batik production process. It was said that the techniques were common practices in India. Pigeaud noted that batik production was not mentioned in Javanese manuscripts in XIV century, however he said that in that day (XIV century) batik was possibly imported from India and worn only by the haves who able to afford it, Batik cloth was part of important textile trade between India and the Archipelago (now Indonesia) that was initiated by indigenous traders and then taken over, and massively extended, by the merchants of Portugal, the Netherlands, and Britain. India was an intermediary of trading in the Archipelago of XVII century and maintained its special position until the beginning of XIX century (Prisma, 5 May 1987:56).

According to Pigeaud the account of batik production on batik production in Javanese manuscript of XIV century pointed out that Indian batik technique significantly contributed to the batik development of that time, although in many respects Islamic influence of Mataram kingdom managed to end the dependency on India.The first step of Javanese batik to determine its motif was taken in XIX century, especially in southern Central Java in Surakarta and Yogyakarta regions, which are well-known as traditional batik production center thanks to the skill and capability of Javanese to produce that artistic craft as folk batik.

As batik development went into Palace in XVIII, some folk batik artists also went into Palace. The position of folk batik artists were raised as they acquired status as royal servant of the Palace. Around 1769 Sususuhan (ruling monarch's title) of Surakarta Hadiningrat issued a formal decree (Javanese: pranatan) that "Jilamprang" motif is forbidden for anyone except the monarch himself and his descendants. In 1785 the Sultan of Yogyakarta initiated parangrusak pattern for his own interest. Then in 1792 and 1796 the palace officials issued further restrictions to regulate certain patterns to wear in the palace such as sawatlar, parangrusak, cumengkirang, and udan liris (Sudarmono 1990: 2).

One example: a group of batis artisans of Wicitran family went into Surakarta Hadingingrat Palace and were bestowed noble rank of the palace. Mrs. Reksowicitro, a batik maker from Soniten, Surakarta, was raised from kawulo (ruled person) status into an abdi dalem (royal servant) in the palace to hold "Abdi Dalem Kriya" titlle with the rank "Hamong Kriya" for her skills. KRT Yosodipuro, in an interview, said that in the palace of

\footnotetext{
${ }^{1}$ Javanese concept of universe creation (cosmology), such a combination of two worlds was known as syncretisme, which is an interactive process between different principles and cultures (Sujanto 1992:14). The interaction has given to Javanese culture the characteristic of continuity, that is the cultural change without abandoning cultural root as its main culture (local genius). This is what Primadi called cultural evolution (see Primadi 1970: 24-34).
} 
Surakarta doing batik work skillfully was an honorable job and enables to put the children of the palace into higher position. Vertical mobility of Abdi Dalem Kriya that they desired had positive impact on their families' prosperity. It was true because they acquired significant economics facilities and their status was raised from lower noble rank. Palace batik maker as a noble rank is exclusively reserved for female batik artisan that was positioned as servant for keputrian (womanhood) palace. The title of Hamong Kriya she had acquired posed a responsibility for her to lead batik work in the Palace. (Rajiman 1986: 93) Such a phenomenon has underlined the fact that folk batik developed outside the Palace was brought into it and was legitimized by the monarch as palace batik. Batik produced subjects thus was labeled as palace-produced batik and eventually was called as classical batik.

Batik is a reflection of glorification culture because (1) Batik as glorification source has served as guidance (philosophy) and inspirational source for subsequent batik production and development; (2) As a work of beauty batik has also became a teaching (concept: guidance and performance). From Javanese culture point of view batik, in addition to its beauty, is a tuntunan (guidance) illustrated on classical batik motif. That is way batik is called an Indonesian great heritage, and even the world now considers it as world cultural heritage.

The cultural engineering of batik by the noble bureaucrats to raise batik status among palace circle has, in a sense, inspired people to regard batik with esteem. Batik, which originally was folk product, has been raised its function to serve as palace bureaucratic dress code of that time. Batik then became "exclusive" goods for the common people, it goes without saying that eventually the forms and types of palace batik has become reference for batik production in the future.

Classical batik motifs were referred and adopted by batik productions in regions far from the palace. Classical batik motifs thus, more or less, would refer (imitate) orientate to the palace batik product, which is regarded as reliable source of standardized motifs. Palace batik is then considered as classical batik and reference for subsequent batik productions. Value and status of the monarch and palace as glorification source is the authority that brought forth cultural trust and motivation. Further development of batik in everyday life has made it as a clothing desired by society for it value and status. The society's impression of the court as cultural center is deeply entrenched; this is the explanation why batik remains a favorite item among Javanese society (Dharsono, 1990: 45).

The decline of palace batik has led the growth and development of regional batik (outside the palace). Regional batik development has remained refer to palace batik as the source of value, status, and glorification inspiration. The development of regional batik (Surakarta and surrounding area) began to reach its peak in the beginning of XX century, in 1930s. A case study conducted by KRT Harjonegoro has offered illustration of batik development in Surakarta that reached its peak from 1930s to 1960s as indicated by batik centers in Surakarta area. The centers in question are BekonangVillage in Mojolaban Subdistrict, Kedunggudel in Were Subdistrict, Sukuharjo District, Matesih Village in Matesih Subdistrict, Karanganyar District, Laweyan in Surakarta, and Tembayat in Klaten District. These regions are key points of recent batik development (Interview with Harjonegoro 1990). Around 1978, traditional processes of regional batik production were heavily pressed by modern printing technology. The impact of technical change is very deep especially with regard to work force placement in the industry (Prisma, 5 May 1987). Consequently, regional batik began to collapse and bankrupt and was replaced by printing batik or manufactured batik sold per meter.

\section{Classical view}

The orientation of Javanese point of view in seeing, perceiving, and behaving is also revolving around cultural source. "Javanese cultural process is in harmony with society's dynamics referring to supreme cultural concept "sangkan paraning dumadi" (see Geertz 1981: X-XII). The birth or existence as a result of relationship between human and God through birth process, live and embracing life, are the result of cause and effect process. Geertz has correlated these issues with some terminologies of Java Religion ${ }^{1}$ that are crystalized in a main principle called "sangkan paraning dumadi". This concept, in Javanese culture, is known by the term of nunggak semi. ${ }^{2}$

\footnotetext{
${ }^{1}$ The emergence of Agama Jawa (Javanese Religion) that refers to ancestor worship (Geertz 1981) is corrected by HarsjaBachtiar, based on a research of Javanese people in Suriname (1976). In fact the Javanese Religion is not ancestor worship religion, it as a beilef that is cristalized in a principle called sangkanparaningdumadi. However, it is important to note that both Clifford Geertz adnHarsjaBachtiar are able to inform about religious system of Javanese social life in a cultural life map with regard to relationshipbetween the existing social structures within society, relationship between organization system and symbols manifestation (1981: X-XII).

${ }^{2}$ Nunggak semi: tunggak literally tree stump while semi means sprouting, Thus nunggak semi means a growth of something from its main culture (its tree stump). A change process (development) of a cultural behavior at a certain phase still refers to
} 
This view is applicable for any classical traditional art including batik. Microcosmic, metacosmic, and macrocosmic relations are closely related with the concept of Triloka/buana. Abdullah Ciptopawiro said that Arjunawiwaha (XI century) that was composed Empu Kanwa during the reign of King Erlangga is a kakawin (old Javanese poetic meter) of shadow play mythological figures that comprises metaphysical philosophical reflection on personified Being. In this poetic meter God Shiva is pictured as sarining paramatata (the essence of supreme truth), being-non being (sakala-niskalatmaka or sensed and unsensed) that is universe (sakala) origin and destiny (2000: 34-35).

Javanese philosophical teachings implicitly explain micro-macro-metacosmic relation in accordance with Indonesian mythical cultural way of thinking. Macrocosmic view put human being as part of the universe, therefore human being should aware its position in the universe. Micro-meta-macrocosmic views are divided, according to Tribuana/Triloka concept, into (1) alam niskala (immaterial and unsened universe); (2) alam sakala niskala (corporeal and non-corporeal universe) the sensed but unsensed in the same time; and (3) alam sakala (corporeal universe of the world). Human being can move into the three metacosmicuniverse through sakala niskala, that is through intermediary such as shaman or medicine man and through arts. ${ }^{1}$

Associated with mandala concept, the Tribuana concept is one of interactive relations that established a cosmic unity and balance. Related to the metacosmos of three universes concept, the mandala concept is a circle symbolizing a perfect, flawless, intact, complete, thorough universe as an essence, substance, invisible supreme energy that is unsensed yet exist and present. The presence is contained in square space of the circle or the essence in existence. Mandala circle is a cosmos, the regularity and order of the universe, perfect harmony that presents in a square (circle) space that was a chaos in its beginning. The perfect presents in a flaw world, the light presents in a dark world, the supreme presents in a relative world, the order present in chaotic world, the male presents in a female world, the invisible presents in a visible world. Mandala is a totality of elements of existence duality. The Upperwolrd becomes one with Underworld through the Middle world of Mandala. (See Jakob Sumardjo 2003: 67) The society's perception of microcosmos and macrocosmos relation was related by Jose and Miriam Arguelles with ritual forms in mandala concept, a concept of interactive relation that later bring about the unity and balance of "centering" cosmos"2 (1972:85).

Alam Niskala (invisible and unsensed universe) is microcosmos (our inner-self) that able to move into macrocosmos in certain dimension to maintain vertical relation with the macrosomos and maintain it towards Oneness. Alam sakala niskala (corporeal and non-corporeal universe) is sensed and unsensed universe. It is illustrated as tree of life motif in semen rama batik. As macrocosmos, tree of life motif horizontally serves as link to and balances against the ridge of upper world (alam niskala with underworld (alamsakala). Alam sakala (corporeal universe or sensed universe) is illustrated as 8 motifs in semen rama batik that consists of (1) ornaments related to land, (2) ornaments related to air like garuda, bird, fire tongue, and (3) ornaments related to sea or represented by boat or ship.

its main cultur (babon). The tree of life is a result of a cultural development process that traditionaly refers to its cultural essence (Harjonegoro, 15 June 1999).

${ }^{1}$ Dharsono Sony Kartika (ed) (2004), PengantarEstetika, Bandung: RekayasaSain, h. 202-203.

${ }^{2}$ Closely related to the function of purifying the mind and body is centering. It is concentration-making, concentric of organism's out-flowing energies by turning them inward and focusing them through a central point. In this way the biopsychic energies are literally recycled. Any activity which achieves this effect is from centering (Jose and Miriam Arguelle, 1972: 85). The concept of mandala form a balance, a harmony, and a unity that each of them provide energy centrally (centering of life). 


\section{Semen Romo Batik}

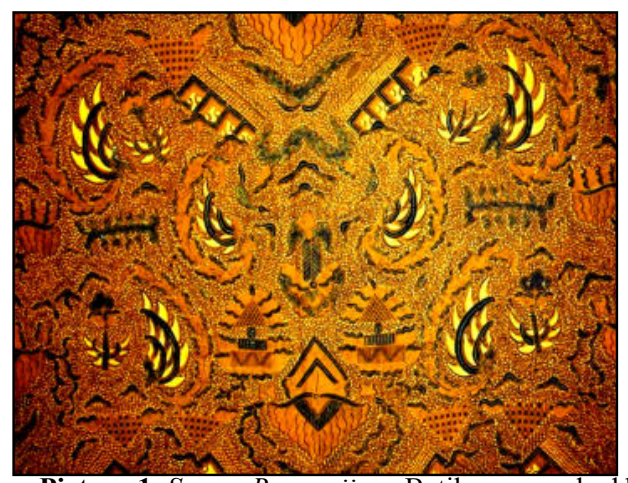

Picture 1. Semen Ramawijaya Batik, approached by the concept of Tribuana/Triloka and mandala, illustrates the relationship between universe or underworld (alam sakala) to move towards Oneness (alam niskala) through middle universe (alam sakala niskala), which bring about the balance, harmony, and unity while each of them gives power/energy centrally.

(Photo: Documentation by Sri Indrati and Kartika, 2004)

From Javanese cultural view semen ramawijaya is beatiful and displays tuntunan (guidance) in its classical motif (based on the concept of Triloka/Tribuana and Mandala). It is as if Semen Ramawijaya batik painted to be seen from above, tree of life is appeared to be surrounded by other motifs. The pattern composition of Semen Ramawijaya batik is motifs combination that consists of tree of life, garuda motifs in left-right sides, under the tree of life is a pair of structures motif under which is a pair land animals motif. With regard to the philosophical concept of Tribuana/Triloka, the tree of life motif as the illustration of intermediary world or middle world (niskala-sakala universe) is a counter balance/link between underwolrd (niskala universe) — through middle world (sakala-niskala universe) — and upperworld (niskala universe).

Philosophically the composition of Semen Rama batik di mandala concept belongs to centering type. The eight main motifs of Semen Rama batik appeared surround tree of life in a pattern that is called Semen Rama batik pattern. The eight motifs bring about balance, harmony, and unity. Each of them gives power or energy centrally, that is to say the surrounding motifs deliver power for tree of life as the center.

The eight motifs of Semen Rama collectively give energy to central motif symbolized by tree of life motif. The tree of life symbolizes obligation character that gives protection and life to the world. This conception is then adopted as Javanese cultural principle of hasta brata. ${ }^{1}$ Hasta brata principle contains philosophical discourse (the destination and view of life) of a leader figure who is wise and put the interest of the world (state) higher than his personal interest (kautaman) as illustrated in Semen Ramawijaya batik with 8 or $9(8+1)$ major motifs. Symbolically those motifs represent hasta brata principle that illustrate the leadership principle as summarizes 8 brata (attitude/character) of true leader and 1 motif as the symbol of microcosmos king.

\section{Conservational View}

Conservational view has inspired subsequent batik production that is called batik conservation. Conservational batik development has then taken the form as revitalization and reinterpretation.

\subsection{Conservation has brought forth revitalization}

\footnotetext{
${ }^{1}$ Hasta brata is a leadership principle that symbolizes 8 brata (attitude/character) of true leader and 1 brata motif that symbolizes microcosmos king: (1) Indrabrata is symbolized as God Indra whose brata is Heaven as the symbol of "darma" and illustrated by tree of life motif; (2) brata Surya is symbolized as God Surya whose brata is Sun that is illustrated by garuda motif; (3) Bayubrata is symbolizes as God Anila/Bayu (Wind God) that is pictured by bird motif; (4) Kuwerabratais symbolized ad God Kuwera whose brata is star (kartika) that is illustrated by sacred weapon motif; (5) Barunabrata is symbolized as God Baruna that illustrated by baito (ship) motif; (6) Agni brata is symbolized as God Agni/Brama whose brata is dahana or fire that is illustrated by fire tongue motif; (7) Yama brata is symbolized as God Yama whose brata is soil (buma) and illustrated by land (meru) motif; (8) Sasibrata is symbolized as God Candra whose brata is moon (candra) and illustrated by land animal motif (in accordance with the character of God Vishnu who incarnates as land animal in his initial incarnation (the second to fourth). Asta-brata subject is the king as leader/ruler and symbolized by throne motif.
} 
The revitalization endeavor has brought about classical batik pattern where batik production as a whole still refers to classis batik. It is true that batik work technique has adopted synthetic coloring matters, but philosophically still refers to the main culture. Classical pattern batik thus, in this regard, can be said as imitation batik (Javanese: tiron, putran). Names of this pattern batik are ofted added with suffix -an to remind of the referred original, for example srikatonan is imitating srikaton batik, sidomukten is imitaion of sidomukti, truntuman is imitation of truntum batik, and so on.

Conservation has resulted in revitalization genre that is called classical pattern batik (Javanese: mutrani). Classical pattern batik is an imitation (Javanese: tiron, putran). Sidomukti batik with black ground is called Sidoluhur (Surakarta style) while its white ground counterpart is called Sidomulyo (Yogyakarta style). Sidomukti pattern batik with black ground is called sidoluhur batik (Surakarta) while sidomukti batik with white ground is called sidomulyo (Yogyakarta). Structurally, sidomukti pattern batik (sidoluhur and/or sidomulyo) is geometrical basic pattern that composes squares. Each square is filled with tree of life, butterfly, building, and garuda motifs.

\section{Sidomukti pattern batik (sidomukten)}

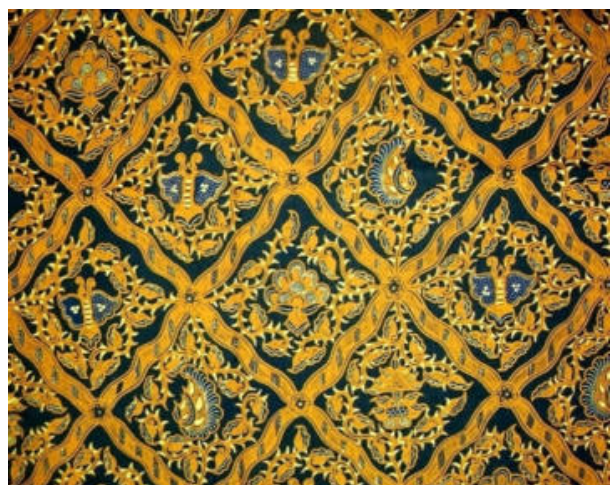

Picture 2. Classical pattern batik is imitation batik (Javanese: tiron, putran). Sidomukti batik with black ground is called Sidoluhur batik (Surakarta style) while its white ground counterpart is called Sidomulyo (Yogyakarta style) (Photo: Documentation by Sri Indrati and Kartika, 2004)

Close examination of patterns (basic motif pattern) reveals the following: Pattern 1: Tree of life pattern appears that its top and lower partsare flanked by a pair of garuda motifs, while its middle part is flanked by a pair of buildings; Pattern 2: Tree of life appears that its top and lower parts are flanked by a pair of garuda motifs while its middle part is flanked by a pair of butterflies. Both Sidomukti and Sidomulyo batiks are symbolim of the principle of sido and mukti, luhur, or mulyo. In Javanese sido literally is "to be" while mukti is honor, it means that to acquire glory (honor) is to be bestowed gift provided by the Almighty. This verbal notion is reflected as symbolism that is illustrated by 4 main motifs of sidomukti, sidoluhur, or sidomulyo that contain the principle of life's honor. Honorable life will only be attained by human being by controlling four passions: amarah passion, lawwamah passion, supiyah passion, and mutmainah passion. This idea is well conformably with Javanese philosophy that guides man to determine his existence in time system and cosmic space that make an inseparable unity between him and the universe. The idea is known by Javanese society as kiblat papat kelima pancer. Life's honor (sidomukti/sidomulyo) can only be attained by self-controlling with regard to four human characters, man will attain kasampurnan sejati (the real life perfectness) if man able to subjugate passions (control over the four passions mentioned before), then man will have heart that waskita (self-control and self-konwledge) and eventually will acquire the honor of sangkan paran (the Will of Almighty).

\section{Semen Remeng pattern batik}

Semen Remeng batik with black ground (Surakarta) and Semen Remen with white ground (Yogyakarta) in term of structure is motifs (patterns) combination that consists of 5 main motifs namely tree of life, garuda, bird, building, and meru motifs. The pattern is composed as follows: tree of life and meru motifs are flanked by a pair garuda motifs in the left and right of lower part and in lower part and between them is a pair bird motifs in flying 
position, di the right-life of the top and the top there are three building motifs upon which is meru motif combined with bird motif. It seems that all of them guard the existence of the tree of life.

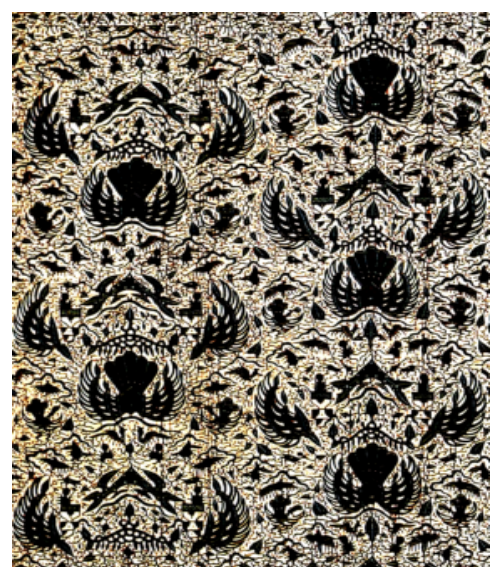

Picture 3. Classical pattern batik is imitation batik (Javanese: tiron, putran). Remeng batik with black ground is called remengan (gurdan) batik (Surakarta style) while its white ground counterpart is called Sidomulyo (Yogyakarta style).

(Photo: Documentation by Sri Indrati and Kartika, 2004)

In Semen remeng (gurdan) batik the tree of life motif is flanked or surrounded by garuda motif that each is purposively larger than tree of life motif. The tree of life symbolism as counterbalance is seemingly protected its existence, it illustrates microcosmic relation (vertical relation between our inner-self and God) and macrocosmic relation (relationship between our inner-self with the universe and its environment). The tranquility and happiness of life (illustrated as shape that is remeng or obscure) can only be obtained by man by controlling four human passions: amarah passion, lawwamah passion, supiyah passion, and mutmainah passion, as suggested by symbols illustrated in Semen Remeng batik pattern showed above. The idea is well conformably with Javanese philosophy that guides man to determine his existence in time system and cosmic space that make an inseparable unity between him and the universe. The idea is known by Javanese society as kiblat papat kelima pancer. Wearing Semen Remeng batik Javanese man expects to attain happiness and tranquility in life that is obscure. The symbolism offers self-controlling principle for man to attain nur-rasa in his life to achieve kasampurnan sejati (the real life perfectness), which is inner-self light in his life.

\subsection{Conservation bring about reinterpretation shape}

Reinterpretation shape has brought about creative pattern batik where batik making is no more entirely referring to classical batik, and both coloring and batik work technique (stamp or printing) are free and utilizing synthetic coloring materials. Philosophically refers to modern aesthetic, creative genre has brought about free motif batik and batik work is no longer referring to classical batik. Coloring and batik work techniques are free and synthetic coloring materials are used. Although conceptually and philosophically refer to modern aesthetic, stylistic illustration technique remains rigidly observed. 
uㅔ

a. Creative pattern batik (Javanese: tangguh)

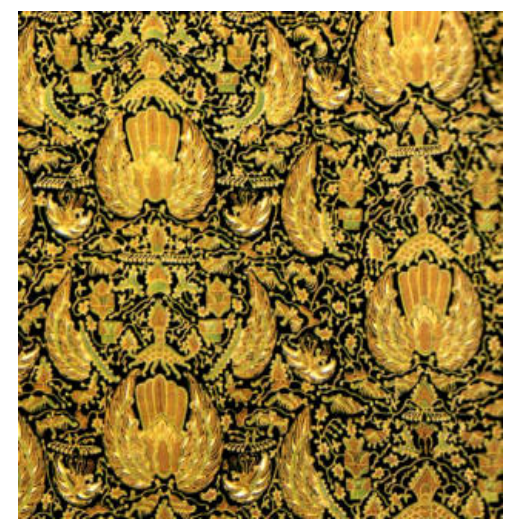

Picture 4. Batik production is no more entirely referring to classical batik, and both coloring and both work techniques are free and utilizing synthetic coloring materials, and philosophically refers to conservational revitalization concept. (Collection of H. Santosa Doelah, 2002, scan repro: Kartika, 2015)

Although creative pattern batik is still produced in reference to traditional batik (see Semen Rama creative pattern batik) and structurally is still referring to traditional pattern, the creative pattern batik is not entirely imitating the traditional. For example: Semen Rama batik shown above has no more 9 motifs $(8+1)$ but less in number, so it does not represent hasta brata principle that philosophically belongs to revitalization concept (tangguh).

Creative batik is made based on modern art concept, thus structurally batik refers to modern aesthetic concept. Creative batik is referring no more to philosophy but to personal expression. Creative batik depends on elements such as motifs that are composed according to arrangement concept that comprises design element, design principle and design foundation. Creative batik depends on how its creator expresses his or her idea personally and is not bound anymore to pakem or philosophy. That is way batik now is richer in variations and freer.

\section{b. Creative batik (expression)}

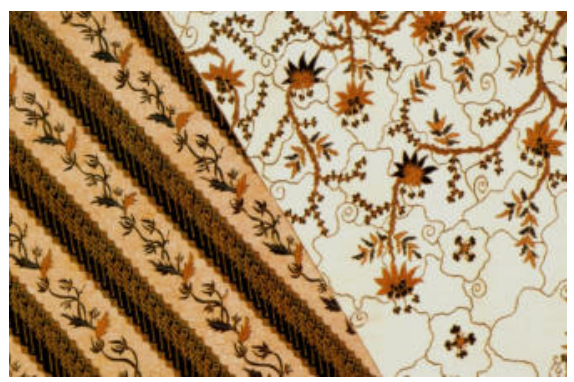

Picture 5. Creative batik is more free but still adaptive to its surrounding environment.

(Collection of H. Santosa Doelah, 2002, scan repro: Kartika, 2015)

The dynamics of batik from classical culture to the emergence of present batik has shown the cultural resilience in the form of preservation and development in accordance with the demands of individual and society, environmental resources, and prevailing social customs of Javanese society. The fine canting batik (hand-drawn batik) that achieved its glorious period around 1910 as palace batik was defeated around 1930s by stamp batik, and subsequently replaced by batik motif cloth until 1979. However, batik alus (classical batik) has managed to regenerate as favorite piece of high-class consumer, batik alus has become exclusive batik. Fine canting batik cloth is chosen and bought by high-class consumers as party dress.

The development of batik has shifted the interest of batik consumer. Common people have turned to batik motif textile while Indonesian bourgeoisie wear fine batik cloth (hand-drawn batik) for formal occasion and formal party. Such a dynamics has ushered hand-drawn batik (canting batik) to its exclusive throne. Hand-drawn batik 
that is developing has, in fact, distinct position in its existence. Hand-drawn batik entrepreneurs have become foster children of batik industry that market their products with distinct specification. It means that batik has cultural resilience in accordance with the prevailing social customs, and cultural resilience is an evidence of national resilience.

\section{CONCLUSION}

This study has revealed (1) classical view of Javanese people when they see and understand things and behave accordingly with constant reference to the cultural source. "Javanese cultural process conforms to social dynamics, which refers to supreme cultural concept "sangkan paraning dumadi" (the origin and destination of mankind). The concept is also known, in Javanese culture, with the phrases nunggak semi (sprouting stump) or mutran $i$ (to make offspring). (2) The conservational view has inspired subsequent batik production to refer to preservation model, i.e. conservation. The conservational development of batik in the form of revitalization and reinterpretation has resulted in the dynamics of Surakarta batik development.

\section{References}

Bernet Kempers, AJ. (1959). Ancient Indonesian Art. Cambridge Massachusetts: Harvard University Press, 60.

Cook, R. (1995). The Tree of Live, Image for the Cosmos. Slovenia: Mladinska Knjiga, 10, 42-43, 50-51.

Cooper, J.C. (1979). An Illustrated Encyclopedia of Traditional Symbols. London: Themes and Hudson Ltd.

Dharsono. (2005). "Pohon Hayat: Simbol dan makna pohon hayat yang terlukis pada batik klasik sebagai ekspresi kebudayaan Jawa". Disertasi Bandung: ITB.

Dharsono (Sony Kartika). (2004). Pengantar Estetika. Bandung: Rekayasa Sain, 202-203.

Hadi, S. (1979). Metodologi Research I. Yogyakarta. Yayasan Penerbitan Fakultas Psikologi Universitas Gajah Mada. Hadiwijono, H. (tt). Kebatinan Jawa dalam Abad 19. Jakarta: BPK Mulya, 25.

Hamzuri. (2000). Warisan Tradisional Itu Indah dan Unik, Jakarta: DPK, DirJen Keb, Dir Permuseuman, 235-236.

Holt, C. (1967). Art in Indonesia: Continuities and Change. New York: Cornell University Press, 55-56, 60, 136.

Hoop, A.N.J. Th.a Th. Van Der. (1949). Indonesische Siermotieven, Uitgegeven Door Hiet, Koninklijk Bataviaasch Genootschap Van Kunsten en Wetenschappen, 275-276, 278-284.

Jose and Arguelles, M. (1972). Mandala. Boelder and London: Shambala, 85.

Kawindrosusanto, K. (1956), "Gunungan”. Majalah Sana Budaya. Th.1 No.2 Maret, 81.

Kartoatmodjo, S. (1986). “Arti dan Fungsi Pohon Hayat dalam Masyarakat Jawa Kuno”, Penelitian Yogyakarta: Lembaga Javanologi, 14.

(1983), “Arti Air Penghidupan dalam Masyarakat Jawa, Penelitian, Yogyakarta: Lembaga Javanologi, 10, 12, 16-17.

Kartosoejono. (1950). Kitab Wali Sepuluh. Kediri. Boekhandel Tan Khoen Swie, 14-23

Mulder, N. (1984). Kepribadian Jawa dan Pembangunan Nasional. Yogyakarta: Gadjah Mada University Press, 13.

Pitono, R. (1969). "Pengaruh Tantrayana pada Kebudayaan Kuno Indonesia”. Majalah Basis 18, no. 2: 389-99.

Saletore, RN. (1987). Encyclopaedia of India Culture. Volume II and III, New Delhi: Sterling Publisher Private Limited, 659-665.

Simuh. (1996). Sufisme Jawa: Transformasi Tasawuf Islam ke Mistik Jawa. Yogyakarta: Yayasan Bentang Budaya, 131.

(1988). Mistik Islam Kejawen Raden Ngabehi Ranggawarsita, Suatu Studi terhadap Wirit Hidayat Jati. Jakarta: Penerbit Universitas Indonesia (UI-Press), 131, 340.

Snodgrass, A. (1985). The Symbolisme of the Stupa. New York: Cornell University, 187.

Subagyo, R. (1981). Agama Asli Indonesia, Jakarta, Sinar Harapan dan Yayasan Cipta Loka Caraka, 98-100, 118.

Sumardjo, J. (2003). Simbol-Simbol Artefak Budaya Sunda, tafsir-tafsir pantun Sunda. Bandung: Penerbit Kelir, 87.

Susanto, S. (1980). Seni Kerajinan Batik Indonesia, Departemen Perindustrian RI, Balai Penelitian Batik dan Kerajinan, Lembaga dan Pendidikan Industri, 9, 212, 261,- 263, 236-237.

Triguna, I. B. G Yudha. (1997). "MobilitasKelas, Konflik dan Penafsiran Kembali Simbolisme Masyarakat Bali. Disertasi Doktor, Bandung, PPs Universitas Padjadjaran, 65.

Wiryamartana, I. K. (1990). Arjunawiwaha: Tranformasi Teks Jawa Kuna lewat Tanggapan dan Penciptaan di Lingkungan Sastra Jawa. Yogyakarta: Duta Wacana University Press, 9. 